\title{
Instilling Participatory Planning in Disaster Resilience Measures: Recovery of Tsunami-affected Communities in Banda Aceh, Indonesia
}

\author{
Grace Yuswita Harahap \\ Department of Architecture, Engineering Faculty, Universitas Medan Area \\ grace@staff.uma.ac.id
}

\begin{abstract}
Strategically, if community improvement is to become an important priority in post-disaster recovery efforts, then the spectrum of recovery must be widened to instill disaster resilience measures. In fact, to achieve this goal all efforts should be participatory in the approaches and adopt empowerment as a strategic objective. In post-tsunami areas in Aceh, Indonesia, the Village Planning Guidelines are designed, not only to rebuild the village physically, but also to instill disaster response measures where the ultimate goal is to ensure that the community is self-reliant, highly-motivated and action-oriented. Significantly, the inculcation of such positive attributes in the community will prepare them well for disaster mitigation in the future; in such way that the community enable to carry out effective and appropriate reconstruction stages in comprehensive recovery process. Thus, this study evaluates whether chosen participatory approach in village planning process is capable to empower the affected-community in Banda Aceh. Through survey and personal interview of forty respondents from four most-devastated villages, answers for twenty-two questions derived from five variables as criteria of effective facilitation process, resulted that the community agreed facilitation approaches succeeded to encourage the affected-community to involve actively in planning process. However, answers for twelve questions from three variables of effective empowerment process showed that the community gained empowerment simply to an extent. This is a confirmation to general opinion that facilitation needs longer time in its process to empower community. For this reason, further research is expected to develop specific post-disaster participatory approaches in effort to evolve the capabilitydevelopment level of affected-community.
\end{abstract}

Keywords: participatory planning process; reconstruction activities; recovery of community

\section{Introduction}

\subsection{Disaster Recovery toward Disaster Resilience}

Rehabilitation and reconstruction activities are aimed for recovery. Meanwhile, the aim of the recovery effort is to attain capable community to achieve improvement in their wellbeing and have more sustainable future. The focus should be in capacity building of affectedcommunity through their active involvement in the process (Tobin 1999) cit. in (Esnard 2003). Particularly for developing countries which the communities are characterized, among others, by poverty, injustice, and vulnerability; returning the affected-community to their previous state is not a sign of well-being improvement, instead recovery efforts needs to promote processes to obtain disaster resilient community (Hawkins and Rao 2008); (Mustafa 2003) cit. in (Samaddar and Okada 2006).

Hence, disaster resilient communities is defined as societies that are structurally organized to minimize the effects of disasters and, at the same time, have the ability to recover quickly by restoring the socioeconomic vitality of the community (Tobin 1999) cit. in (Esnard 2003). Thus, post-disaster reconstruction is a process or a development attempt that has two goals, firstly, to help affected-community to overcome damage occurred due to the disaster; and the second, to help the community to upgrade its positive growth where the 
natural hazard is a present as well as potential threats (Samaddar and Okada 2006). These attempts then will better be achieved via community-based approach, as it is believed to be a fundamental element for community resilience (Norris, Stevens et al. 2008).

Most definitions for resilience emphasize a capacity for successful adaptation in the face of disturbance, stress, or adversity. Brown and Kulig argued that individuals and collectives are resilient in two senses. The first, individuals and collectives are called resilient as they act in a way they recover from what defined as negative physical or social events. In the second sense, they are called resilient as they act to transform their physical and social environments to mitigate against such events in the future (Brown and Kulig 1996/97) cit. in (Norris, Stevens et al. 2008). In short, resilience is about having a set adaptive capacities. This set includes capacities that robust, redundant, or rapidly accessible and thus able to offset a new stressor, danger, or surprise (Norris, Stevens et al. 2008).

One of resources for community to have adaptive capacities is community competence. For the goal of recovery efforts to develop disaster resilient communities, empowerment process needs to focus on enhancing community competence; in which via community competence, collective action and decision-making were performed. In Banda Aceh, right after the disaster, the affected-community started from community-based action. Survivors built hand-in-hand a 'community centre' from their village debris, where they could discuss what to do next together. Afterwards, community-based approach carried out by housing assistance agency. Hence, through evaluation of participatory process, this paper explains the extent to which community empowerment achieved during participatory village planning process in post-tsunami Banda Aceh.

\section{Review of Literatures}

\subsection{Community Competence}

Cottrell described a competent community is community who: (1) are able to collaborate effectively in identifying the problems and needs of the community; (2) can achieve a working consensus on goals and priorities; (3) can agree on ways and means to implement the agreed upon goals; and (4) can collaborate effectively in the required actions (Cottrell 1976) cit. in (Rocha 1997).

Community's skills, which were identified by Goodman et al., are essential elements of community competence, i.e. abilities to engage constructively in group process, resolves conflicts, collect and analyse data, and resist opposing or undesirable influences. There appears to be high consensus that critical reflection and problem solving are fundamental capacities for community competence and resilience. Ganor and Ben-Lavy emphasized the importance of 'coping' capacity, which is the community's ability to take action (Goodman, Speers et al. 1998); (Ganor and Ben-Lavy 2003) cit. in (Norris, Stevens et al. 2008).

\subsection{Evaluation of Participatory Process}

The extent to which participatory process for tsunami-affected community achieves its goal to empower the community should be understood through evaluation of the process. However, efforts to evaluate participatory process have been sparse (Rowe and Frewer 2004; Rowe, Marsh et al. 2004). In fact, empowerment is not an autonomous practice that happens by itself; it must be facilitated, guided, and supervised in order to bring about the desired result. For that reason, initially effective facilitation needs to be assessed. It is suggested that the assessment carries out through the achievement of performing the five fundamental purposes of facilitation (Triantafillou and Nielsen 2001). 
Table 1. Criteria and Definitions of Effective Facilitation

Process (Triantafillou and Nielsen 2001)

\begin{tabular}{ll}
\hline \multicolumn{1}{c}{ Criteria } & \multicolumn{1}{c}{ Definitions } \\
\hline 'hand over the stick' & $\begin{array}{l}\text { the locals must be shown concretely how to conduct investigations, } \\
\text { analyses, presentations of themselves in order to learn about } \\
\text { themselves }\end{array}$ \\
$\begin{array}{l}\text { Installation of self-critical awareness } \\
\text { facilitators must openly show how one continuously and critically } \\
\text { examines one's own behaviour }\end{array}$ \\
$\begin{array}{l}\text { introducing new modes of } \\
\text { communication } \\
\text { the facilitator must show how intuition can work in practice } \\
\text { according to the principle: Use your best judgement at all times }\end{array}$ \\
$\begin{array}{l}\text { facilitators must work to open up new ways of sharing information } \\
\text { and ideas between local people and developers; }\end{array}$ \\
$\begin{array}{l}\text { facilitators help the community to help themselves after the } \\
\text { facilitators have left }\end{array}$
\end{tabular}

Furthermore, criteria and definitions of effective empowerment process are derived from the three stages of empowerment process, i.e. position, conscientization, then political action and change (Carr 2003). For the purpose of this study, the empowerment criteria focussed to answer the extent to which people gaining psychological power through conscientization. Thus, variables used for this criterion are Interpretation, Identity, and Mobilization.

Table 2. Criteria and Definitions of Effective Empowerment Process (Carr 2003)

\begin{tabular}{ll}
\hline \multicolumn{1}{c}{ Criteria } & The community is capable to identify their misery as an 'origin position' to move \\
f. Position & The community is capable to identify the causes of the misery, and uncover the \\
II. Conscientization & political roots of people's individual experiences from that misery. \\
& The community is capable to identify common conditions and interpret the effect \\
a) interpretation & of those conditions and thereby become critically aware of their relation to the \\
& The community share their experiences, feelings, and ways of naming which \\
& resulting to the expansion of the range of knowledge. \\
& The community grasp the political interpretation through the given range of \\
& knowledge at a particular historical juncture. \\
& The community enable to create and re-create provisional identities through \\
b) Identity & political interpretation. \\
c) Mobilization & The community enable to reflect a new range of options for action and a new \\
investment in collaborative action. & In the case of community 'failed' action, the community enable to collectively \\
reflect on the new generated understandings of themselves and their circumstances \\
change
\end{tabular}




\subsection{The Recovery Effort: Participatory Village Planning}

Participation as an approach in recovery processes in Aceh and Nias, was endorsed by Presidential Decree 30/2005 of the Republic of Indonesia, namely the Blue Print of Aceh and Nias rehabilitation and reconstruction. In that Blue Print it is also clearly stated that reconstruction "... includes spatial planning”. To speed up the reconstruction, spatial planning process is conducted parallel at various levels, from village to provincial levels; from general spatial plans to detailed and technical plans. The reason for conducting spatial planning simultaneously, among other things, is the need to accelerate the reconstruction process to effectively use the limited available time.

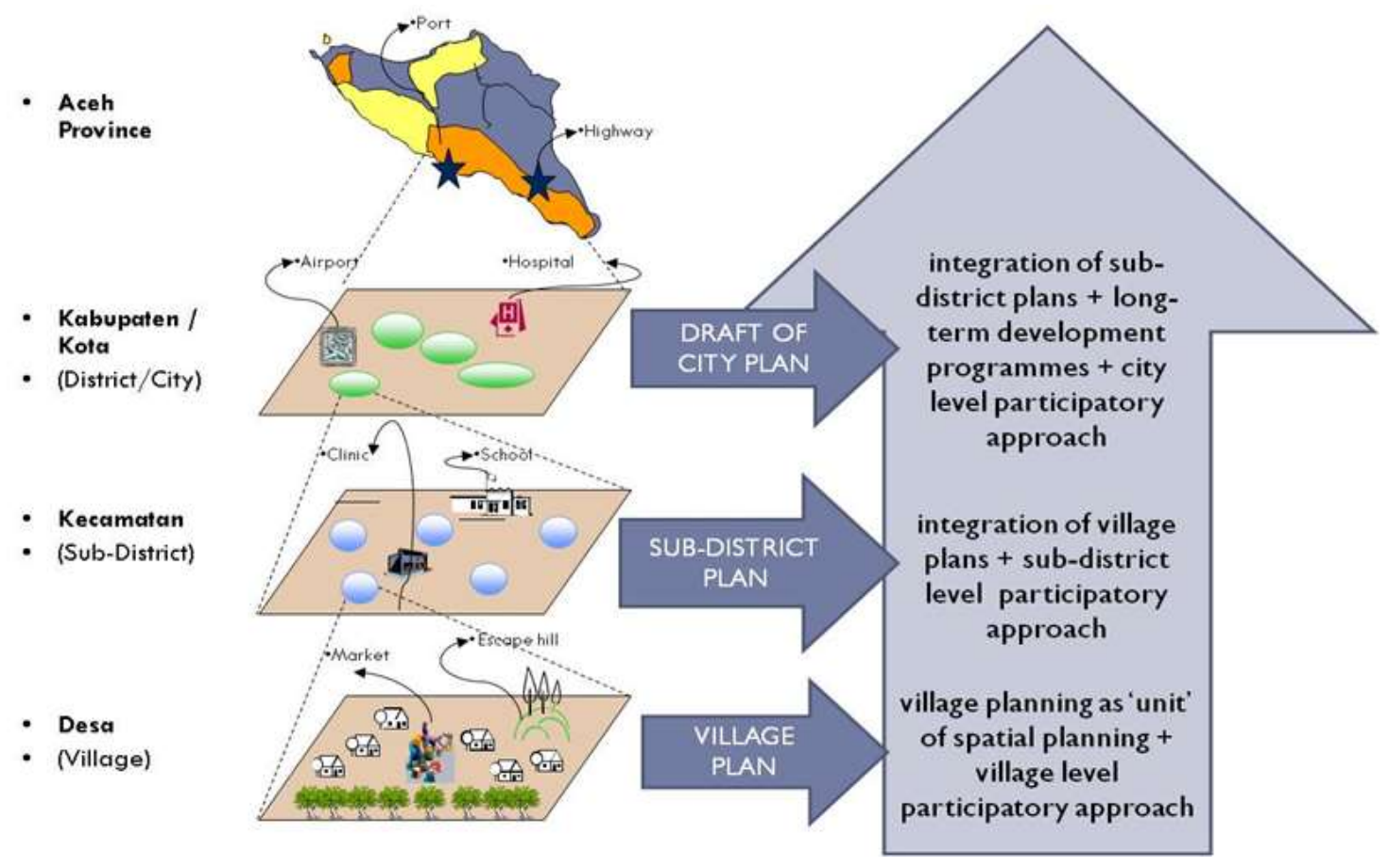

Figure 1. Spatial Planning at Various Levels

Concerning these two legal directions, i.e. the need for spatial planning and for a participatory rehabilitation and reconstruction, there are at least documents and publications which taken a participatory spatial planning approach (BRR, 2009). In addition, reconstruction also has been accelerated by the condition of Aceh province which was in armed conflict between separatist movement-known as National Liberation Front of Acheh Sumatra (also known as GAM) - and national government for almost 30 years before the peace accord was signed in August 2005. This conflict contributed to the nearly paralyzed of the provincial and district/city governments all over the province for the fire engagements and fears. In short, tsunami made none but worsened the existing situation.

In Banda Aceh city, there are 52 villages affected by tsunami (see Figure 2). Among those, 39 villages were reported accomplished by various agencies that carried out the village planning processes. These villages mostly located in coastal areas where the heaviest destruction took place. 

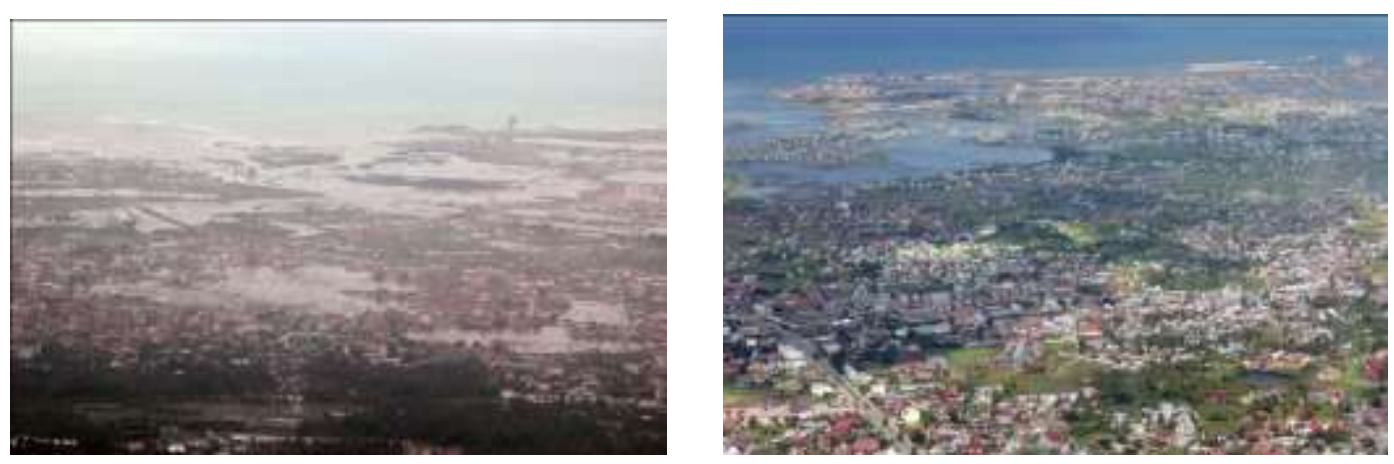

Figure 2. Banda Aceh, Immediately after Tsunami Struck (2005) and after Reconstruction (2007)

For the process of village plan making, BRR provides a Village Planning Guidelines for all parties who participate in the plan-making. "These guidelines are expected to guide all concerns parties in the making of better settlements" (BRR 2006). The guidelines consists of a number of planning activities need to be carried out according to the number of proposed houses to be reconstructed. "...these guidelines also suggest steps to be taken to enable the planned settlements meet the expectations of the people" (BRR 2006).

The goals of participatory village-plan making in post-disaster areas are mainly for facilitating implementation in the context of recovery. Up to four years after the tsunami, evidence of both physical reconstruction and participatory planning processes may be obvious. Considering participatory approach starting from village level (see Figure 3), this study particularly examines participation in village-plan making, which the approach is directly to individuals, as member-of-community, and the community itself, as-a-whole.

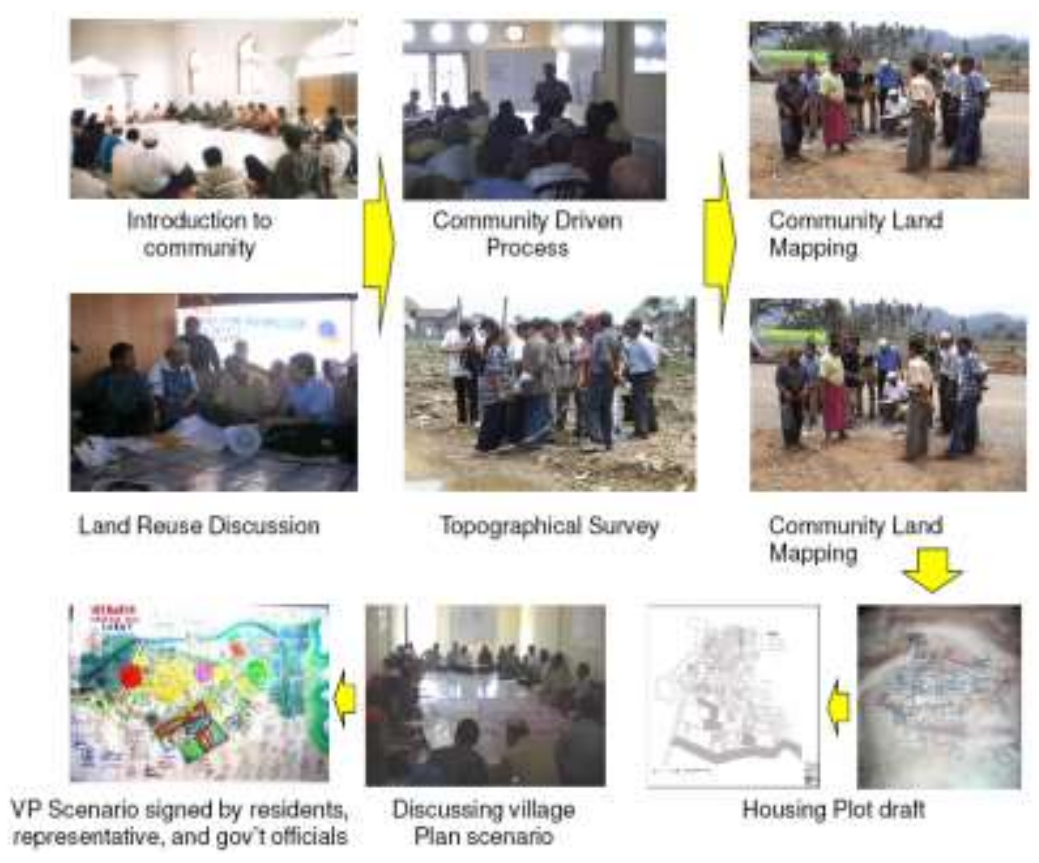

Figure 3. Participatory Village Planning Process 


\section{Research Methods}

The data in this paper is based on a survey study which was collected through questionnaire. The respondents were tsunami-affected individuals who actively involved in participatory village planning process in their own village. Sampling processes of the respondents were through multi-stage cluster sampling and snowball sampling. The identification of 52 affected-villages in Banda Aceh is derived from superimposing three sources 'level of damage' data, i.e. the Blue Print of Aceh and Nias rehabilitation and reconstruction, the Map Frame, and the Study on the Urgent R/R Plan for Banda Aceh-JICA. Among those villages, 39 villages had accomplished-plans, and 18 villages among them were most-destroyed. These villages - categorized as 'inundated-village' for the purpose of this study - were villages which part of the land sank to the sea, and the rest of the land mostly covered with sea water with buildings on it destroyed and swept away by tsunami.
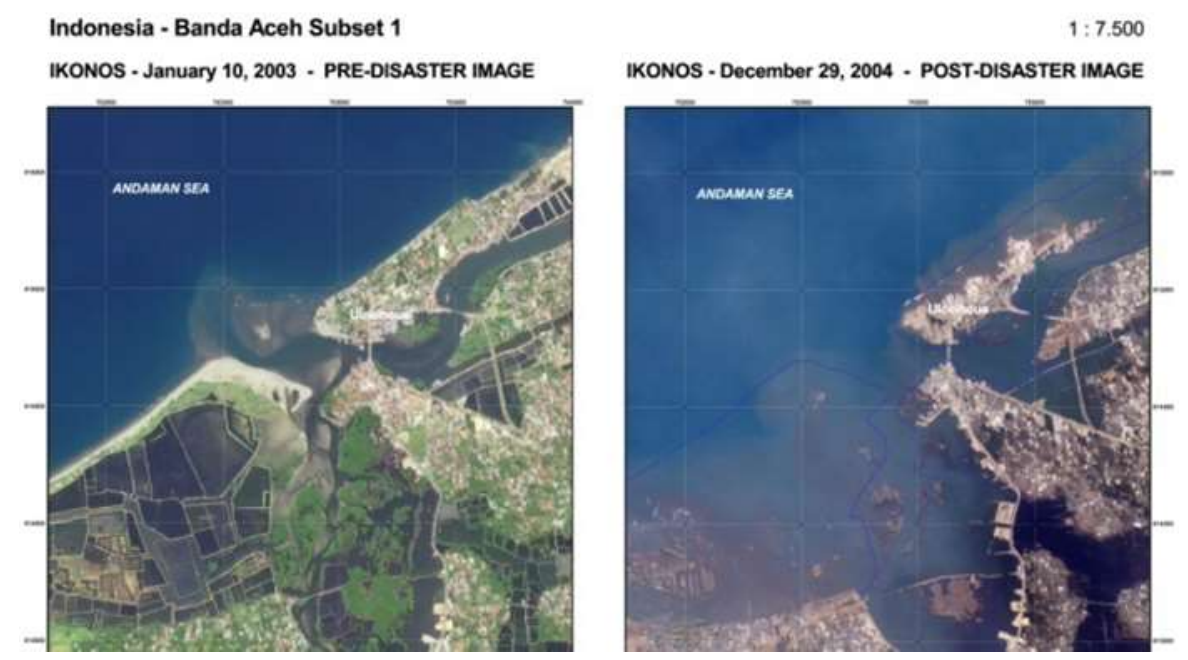

Figure 4. Satellite Image of an Inundated Village in Banda Aceh, before and after Tsunami Struck

Each of these 18 inundated-villages was planned by using one among five village planning methods used in Banda Aceh city. However, they were only four planning methods which carried out in participatory process. These four methods then were carried out for 12 villages' plan-making processes.

The sample of village for each of the four planning methods was determined by multistage considerations, i.e. the most completeness of proceedings of participation process, the availability of record of participants' involvement (attendance list, pictures, and written names), the highest number of community meetings carried out, and the highest number of participated-individuals.

\subsection{Questionnaire}

References for evaluating facilitation and empowerment derived from goals of empowerment and facilitation processes postulated by Triantafillou and Nielsen, as well as Carr (Triantafillou and Nielsen 2001; Carr 2003). The questionnaire, completed by participants and administered face-to-face, consists of three topics for personal information, 
and two topics for the evaluation of facilitation process and empowerment. Each evaluation topic has several questions which addressing similar concept.

Rating scales used to measure the items on the questionnaire is to indicate the respondents' level of agreement or disagreement on a five-point scale running from strongly agrees to strongly disagree. There was a middle point on the scale that allowed for a neutral response ('Abstain'), and one point for 'Don't remember' option.

Table 3. Number of Questions for Each Topic in the Questionnaire

\begin{tabular}{|c|c|c|}
\hline No. & Description & Number of questions \\
\hline \multicolumn{3}{|c|}{ Personal Information of respondent } \\
\hline 1. & General Information & 8 \\
\hline 2. & Involvement & 2 \\
\hline 3. & Availability for interview & 1 \\
\hline \multicolumn{3}{|c|}{ Facilitation and Empowerment } \\
\hline 1. & Facilitation & 22 \\
\hline & Empowerment & 12 \\
\hline & Total Questions & 45 \\
\hline
\end{tabular}

\subsection{Respondents}

Total number of respondents is 40 individuals; consist of 27 males and 13 females. These 40 respondents are in the range of age 29-65 years old, with length of occupancy in the village is between 6-63 years.

Table 4. General Information of Respondents

\begin{tabular}{|l|r|r|r|r|r|r|r|r|r|}
\hline \multirow{2}{*}{ Village } & \multirow{2}{*}{$\begin{array}{c}\text { No. } \\
\text { Respondents }\end{array}$} & \multicolumn{2}{|c|}{ Gender } & \multicolumn{4}{c|}{ Age } & \multicolumn{3}{c|}{$\begin{array}{c}\text { Length of occupancy } \\
\text { in the village }\end{array}$} \\
\cline { 3 - 11 } & & Male & Female & $29-41$ & $42-54$ & $55-67$ & $5-24$ & $25-44$ & $45-64$ \\
\hline Cot Lamkuweueh & 8 & 7 & 1 & 3 & 3 & 2 & 2 & 4 & 2 \\
Deah Glumpang & 8 & 7 & 1 & 6 & - & 2 & 2 & 5 & 1 \\
Punge Blang Cut & 14 & 11 & 3 & 2 & 7 & 5 & 3 & 4 & 7 \\
\hline Lampulo & 10 & 2 & 8 & 7 & 2 & 1 & 3 & 7 & - \\
\hline & $\mathbf{4 0}$ & $\mathbf{2 7}$ & $\mathbf{1 3}$ & $\mathbf{1 8}$ & $\mathbf{1 2}$ & $\mathbf{1 0}$ & $\mathbf{1 0}$ & $\mathbf{2 0}$ & $\mathbf{1 0}$ \\
\hline
\end{tabular}

Positions of respondents are divided into three, i.e. village committee, influencing villager, and community member and the occupations of respondents are divided into four groups, i.e. government officer, private business, retirement, and housewife. 
Table 5. Respondent's Occupations and Positions in The Village

\begin{tabular}{|c|c|c|c|c|c|c|c|c|}
\hline \multirow[b]{2}{*}{ Village } & \multirow[b]{2}{*}{$\begin{array}{c}\text { No. } \\
\text { Respondents }\end{array}$} & \multicolumn{3}{|c|}{ Position } & \multicolumn{4}{|c|}{ Occupation } \\
\hline & & $\begin{array}{c}\text { Village } \\
\text { committee }\end{array}$ & $\begin{array}{c}\text { Influencing } \\
\text { villager }\end{array}$ & $\begin{array}{c}\text { Community } \\
\text { member }\end{array}$ & $\begin{array}{l}\text { Gov't } \\
\text { officer }\end{array}$ & \begin{tabular}{|} 
Private \\
business
\end{tabular} & $\begin{array}{c}\text { Retire- } \\
\text { ment }\end{array}$ & $\begin{array}{l}\text { House- } \\
\text { wife }\end{array}$ \\
\hline Cot Lamkuweueh & 8 & 4 & 1 & 3 & 2 & $\overline{5}$ & & 1 \\
\hline Deah Glumpang & 8 & 4 & 4 & . & 1 & 7 & - & \\
\hline Punge Blang Cut & 14 & 6 & 3 & 5 & 6 & 1 & 4 & 3 \\
\hline Lampulo & 10 & 4 & & 6 & 1 & 1 & 1 & 7 \\
\hline & 40 & 18 & 8 & 14 & 10 & 14 & 5 & 11 \\
\hline
\end{tabular}

\section{Results and Discussion}

All questions for topics of empowerment and facilitation are measured in five-scale rating. For the analysis purpose of this paper, scales of 'strongly agree' and 'agree' are grouped together to be labelled 'agree'. The other scales, i.e. 'strongly disagree', 'disagree', 'abstain', and 'don't know' option will be grouped together and mentioned by 'disagree and uncertain'.

\subsection{Facilitation Results}

Questions in facilitation topic are divided into five sub-topics, i.e. Self-facilitation exercises, Installation of self-critical awareness, Invoking personal responsibility, Introducing new modes of communication, and Reflective capacity.

Self-facilitation exercises sub-topic is intended to obtain information whether by facilitation the community has known how to conduct investigations, analyses, presentations of themselves in order to learn about their own-selves. More than $90 \%$ of respondents were convinced that they are able to facilitate themselves.

Installation of self-critical awareness sub-topic is to identify whether by facilitation the communities know how to continuously and critically examine their own behaviour. Response of respondents is more than $70 \%$ positive. The process of installation of self-critical awareness of communities for the purpose of assisting community in reconstruction activities was succeeded.

Invoking personal responsibility sub-topic is to identify whether the facilitators shown how intuition can work in practice, by using communities best judgement at all times. Responses of participants are quite convincing. More than $80 \%$ of respondents confirmed that facilitation processes succeeded to show how intuition practicable to make decision for community recovery by using best judgement of the community themselves.

Introducing new modes of communication sub-topic is to obtain information whether facilitators have worked to open up new ways of sharing information and ideas between local people and developers. Responses of participants are mostly positive. More than $80 \%$ of respondents confirmed that facilitators succeeded to open up new ways of sharing information and ideas between local people and developers.

Reflective capacity sub-topic is to identify whether facilitators help the community to help themselves after facilitators have left. Response of respondents showed disagreement and uncertainty on all the three issues: first, more-or-less $17 \%$ of them were disagreed and uncertain that the planning process has formed the basis for strengthening the community to be self-help. Second, $20 \%$ of respondents were disagreed and uncertain that the facilitators have prepared the community to help themselves, later after facilitators have left. However, it is a curious paradox that among the positive agreements the respondents gave to previous questions, half of the respondents admitted that the capability of community was not 
convincing in order to organize them to carry out next reconstruction processes without assistance from facilitators.

In summary, in the context of recovery efforts, facilitation process was succeeded to achieve the goal was set for it, i.e. encouraging active involvement of community in planmaking process for the implementation of reconstruction. However, the 13-50\% range of disagreement and uncertainty on a number of issues in facilitation process shows that the process was not fully succeeded if the aim of recovery efforts is to develop resilient community. Regardless to other influencing factors of community competence, such as collective efficacy, it is clear that longer time and strategic participatory arrangement are needed to facilitate the community to be more empowered reaching satisfactory level of competence to be disaster-resilient community.

\subsection{Empowerment Results}

The questions in empowerment topic are divided into three sub-topics, i.e. Interpretation, Identity, and Mobilization. Interpretation sub-topic is intended to obtain information whether the affected-communities are capable to interpret their positions and relationships in society. Responses of participants to these questions are mostly positive. More than $70 \%$ of respondents were convinced that the tsunami-affected individuals succeeded in joining with others to identify common condition and interpret the effect of those conditions and thereby become critically aware of their relation to the environment, especially to the realities they faced.

Identity sub-topic is intended to obtain information whether the affected-communities are capable to create and/or recreate an identity in relation to their environment, and effecting social change. More than $90 \%$ of respondents convinced that through the interpretative process of the condition as tsunami-affected communities, provisional identities are created and recreated.

Mobilization sub-topic is intended to obtain information whether through interpretation and identity new range of options for identification and action, as well as a new investment in collaborative action emerged in communities. Responses to these questions are mostly positive. More than $80 \%$ of respondents confirmed that they involved in collaborative action of housing reconstruction in their village.

From the above three sub-topic of empowerment, it can be concluded that the empowerment was achieved to an extent. However there were disagreement and uncertainty mostly about various capabilities which supposedly achieved via empowerment process in the efforts toward community resilience. In this case, guidance and expertise from the professional assisted the community to gain knowledge to participate in decision-making processes in their village plan-making from an informed position. The community then capable to mobilize its members to support the reconstruction programmes in the village. Nevertheless, to be a disaster resilient community, the competence of community needs to be enhanced via empowerment. For the empowerment depends on how it was facilitated, then it is needed to learn responses of respondents on facilitation process.

\section{Conclusion}

This paper presents the process of enhancing community participation in post-tsunami Aceh through instilling disaster resilient measures in order to ensure comprehensive and effective community recovery efforts. Results from this study show that combination of village planning process with the implementation of the plan is required. The underlying reason for this is as empowerment gained over time efforts to extent facilitation period for individuals and community is essential. It means each step of planning activities then 
followed by the implementation along the lines of a 'needs and capabilities' basis of community. It is expected in every step of planning and implementation activities, individuals and community enhance their competence and, at the end, gain socio-political empowerment. Arguably, this can be a tool for the government to plan for and assess the on-going village reconstruction exercise and also as a coordination mechanism of all participating partners.

Thus, certainly, there are challenges of this proposed approach. Developing sociopolitical empowerment itself demands time, commitment, and the development of a great deal of organizational and community financial and material resources (Rocha 1997). The planning practitioners need to be capable to design comprehensive planning activities for particular community with its socio-political context. Along with this, planning and implementation actors need to be in the same spirit to empower affected-individual and community. In addition, the donors need to be aware of financial and material resources needed for this approach and also of flexibility of resources allocation. Bigger challenges may come from local and national policies and institutional arrangements. At the end, the key factor for the successfulness of this proposed-approach relies on local human resources in managing this comprehensive post-disaster development programmes.

\section{Acknowledgments}

The field work of this research is supported by the Universiti Sains Malaysia through Postgraduate Research Grant Scheme (USM-RU-P GRS) 2009, account no. 1001/PPBGN/832062.

\section{References}

Brown, D. and J. Kulig (1996/97). The Concept of Resiliency: Theoretical lessons from community research. Health and Canadian Society 4: 29-52.

BRR (2006). Village Planning Guidelines. BRR. Banda Aceh, BRR. BRR.1/1.04 B/01.01/2006: 31 .

BRR. (2009). Direktori Dokumen Produk Rehabilitasi dan Rekonstruksi Bidang Penataan Ruang. Banda Aceh: BRR.

Carr, E. S. (2003). Rethinking Empowerment Theory Using a Feminist Lens: The Importance of Process. Affilia 18: 14.

Cottrell, L., Jr. (1976). The Competent Community: Further Explorations in Social Psychiatry. B. Kaplan, R. Wilson and A. Leighton. New York, Basic Books, Inc.: 195209.

Esnard, A.-M. (2003). Beyond Semantics and the Immediate Postdisaster Period: Community quality of life as an overarching theme for sustaining collective action. Natural Hazard Review 4(3): 7.

Faizin, R., Raidayani, Nugroho, Y., and Yanti, I. 2020. Sun-Dried Bilimbi (Averrhoa Bilimbi L) as an Additional Income For Housewives In Ujong Tanoh Darat Village, Meureubo SubDistrict, Aceh Barat Regency, Aceh. Budapest International Research in Exact Sciences (BirEx) Journal (2): 184-187.

Ganor, M. and Y. Ben-Lavy (2003). Community Resilience: Lessons derived from Gilo Under Fire. Journal of Jewish Communal Service Winter/Spring: 105-108.

Goodman, R., M. Speers, et al. (1998). Identifying and Defining the Dimensions of Community Capacity to Provide a Basis for Measurement. Health Education \& Behavior 25: 258-278. 
Hawkins, C. A. and P. N. Rao (2008). CEDER: A Social Development Response to the Tsunami Recovery in Tamil Nadu, India. Social Development Issues 30(1): 19.

Ismail, Salahuddin, S., and Amirulkamar. 2019. Social Changes in the Post-Tsunami Banda Aceh City. Budapest International Research and Critics Institute-Journal (BIRCIJournal) (2): 45-50.

Monang, S. 2018. Reconstruction of Western Civilization Viewed by Sayyid Abû alasanas' Alî al-Ḥasanî al-Nadwî. Budapest International Research and Critics Institute-Journal (BIRCI-Journal) (1): 1-12.

Norris, F. H., S. P. Stevens, et al. (2008). Community Resilience as a Metaphor, Theory, Set of Capacities, and Strategy for Disaster Readiness. American Journal of Community Psychology 41: 127-150.

Rocha, E. M. (1997). A Ladder of Empowerment. Journal of Planning Education and Research 17: 31-44.

Rowe, G. and L. J. Frewer (2004). Evaluating Public-Participation Exercises: A Research Agenda. Science Technology Human Values 29(4): 46.

Rowe, G., R. Marsh, et al. (2004). Evaluation of a Deliberative Conference. Science Technology Human Values 29(1): 35

Samaddar, S. and N. Okada (2006). Participatory Approach for Post-Earthquake Reconstruction in the Villages of Kachchh, India. Annuals of Disas. Prev. Res. Inst., Kyoto Univ. 49 B: 9.

Tobin, G. A. (1999, June). Sustainability and community resilience: the holy grail of hazards planning? Global Environmental Change Part B: Environmental Hazards, 1(1): 13-25.

Triantafillou, P. and M. R. Nielsen (2001). Policing Empowerment: The Making of Capable Subjects. History of The Human Sciences 14(2): 63-86. 